Savunma Bilimleri Dergisi

The Journal of Defense Sciences

May1s/May 2018, Cilt/Volume 17, Say1/Issue 1.

ISSN (Bas111) : 1303-6831 ISSN (Online): 2148-1776

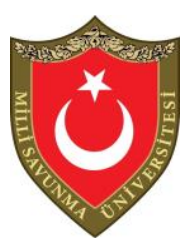

\title{
Askerî Sistemlerde Nanoakışkan Uygulamalarının Sayısal Íncelemesi
}

\author{
Mustafa KILIÇ*
}

$\ddot{O} z$

Bu çalışmada; askerî sistemlerin gelişen teknolojiye bağll olarak artan ısıl yük problemini çözmek maksadıyla, nanoakışkanların çarpan akışkan jet tekniği ile kullanılarak, yüksek ısı akılı bir yüzeyden olan ısı transferinin iyileştirilmesi sayısal olarak incelenmiştir. Farklı Reynolds sayıları (Re $=2000,4000,6000,8000)$ ve farkl tipte hazırlanan nanoakıskanların $\left(\mathrm{Cu}-\mathrm{H}_{2} \mathrm{O}, \mathrm{CuO}-\mathrm{H}_{2} \mathrm{O}, \mathrm{TiO}_{2}-\mathrm{H}_{2} \mathrm{O}, \mathrm{Al}_{2} \mathrm{O}_{3}\right.$ $\left.\mathrm{H}_{2} \mathrm{O}\right)$ ısı transferine etkisi bu çalışmada kullanılan parametrelerdir. Çalışmada düşük Reynolds sayılı k-E türbülans modeli kullanılmıştır. Sonuç olarak; Re sayısı arttıkça yerel $\mathrm{Nu}$ sayısının arttığı görülmüştür. $\mathrm{Cu}-\mathrm{H}_{2} \mathrm{O}$ nanoakışkanı için $(20 \mathrm{~nm}$ parçacık çapında, \% 4 hacimsel oranda) Re sayısı 4000-8000 aralığında artırıldiğında $N u_{\text {ort }}$ sayısında \%47,2'lik bir artış elde edilebildiği tespit edilmiştir. $\mathrm{Cu}-\mathrm{H}_{2} \mathrm{O}$ nanoakışkanı kullanılması durumunda, ortalama Nusselt sayısında sirastyla $\mathrm{CuO}-\mathrm{H}_{2} \mathrm{O}, \mathrm{TiO}_{2}-\mathrm{H}_{2} \mathrm{O}, \mathrm{Al}_{2} \mathrm{O}_{3}-\mathrm{H}_{2} \mathrm{O}$ ve saf suya göre $\% 2,6, \% 5,5, \% 6,1$, \%9,6 iyileşme olduğu görülmüş̧ür. Sayısal modelde kullanılan düşük Reynolds sayılı k-ع türbülans modelinin sıcaklık dağılımını ve akış özelliklerini oldukça iyi bir şekilde temsil edebildiği görülmüştür.

Anahtar Kelimeler: Biyolojik sistemler; çarpan akışkan jet; ısı transferi; nanoakışkanlar.

* Dr.Öğr.Üyesi, Adana Bilim ve Teknoloji Üniversitesi, Mühendislik Fakültesi, Makine Mühendisliği, mkilic@adanabtu.edu.tr. 


\title{
Numerical Investigation of Nanofluid Applications in Military System
}

\begin{abstract}
In this study, enhancement of heat transfer from high heat flux surface was investigated numerically by using nanofluids and impinging jet technique to solve the problem of increasing heat loads which is caused by developing technologies of military sistems. Effect of different Reynolds number (Re=2000, 4000, 6000, 8000) and different type of nanofluids (Cu-H2O, $\mathrm{CuO}-\mathrm{H} 2 \mathrm{O}$, TiO2-H2O, Al2O3-H2O) on heat transfer are the parameters of this study. Low Re $k$-E model was used. It was obtained that increasing Re number causes an increase on local Nusselt number. Increasing Reynolds number from 4000 to 8000 causes an increase of $47.2 \%$ on average Nusselt number for $\mathrm{Cu}-\mathrm{H} 2 \mathrm{O}$ nanofluids (particle diameter of $20 \mathrm{~nm}$ and volume ratio of 4\%). It was determined that using $\mathrm{Cu}$-H2O nanofluid causes an increase of $2.6 \%, 5.5 \%, 6.1 \%$ and $9.6 \%$ on average Nusselt number with respect to $\mathrm{CuO}-\mathrm{H} 2 \mathrm{O}$, TiO2-H2O, Al2O3-H2O and pure water. It was seen that the low Reynolds number $k$ - $\varepsilon$ turbulence model well represents the temperature distribution and flow properties at this study.
\end{abstract}

Keywords: Biosystems; impinging jets; heat transfer; nanofluids.

\section{Giriş}

Günümüzde askerî teknolojilerin hızla gelişmesi, enerji gereksinimini artmakta, buna karşı1ık bir yandan enerji kaynaklarının kısıtlı olması, diğer yandan da enerji sağlanması ve kullanılmasında çevre sorunlarının getirdiği sınırlamalar, mevcut enerji kaynaklarının daha verimli bir şekilde kullanımını ve yeni teknoloji arayışlarını da beraberinde getirmektedir. Gelecek yüzyılın teknolojisi olarak değerlendirilen nanoteknoloji ise bu teknolojik kırılmayı sağlayacak önemli bir adım olarak değerlendirilmektedir (Sun vd., 2016). 
Nanoteknoloji alanında yapılan önemli çalı̧̧malardan birisi de nanoakışkanların kullanılmasıdır. Geleneksel 1sı transferi akışkanlarının içerisine belli parçacık büyüklügü ve hacimsel oranlarda katılarak oluşturulan süspansiyonlara "nanoakışkan" denir. Nanoakışkan kullanılarak yapılan 1S1 transferi uygulamalarında; akışkan içerisine süspanse edilen parçacıklar akışkanın 1sıl kapasitesini arttırırlar. Parçacıklar arasındaki etkileşim ve çarpışmalar akış geçiş yüzeyinde çalkantılara ve türbülans şiddetinin artmasına neden olur (Teamah vd., 2015). Daha yüksek 1sı iletimi ile birlikte çalkantı şiddeti ve geniş yüzey alanı daha çok 1sı transferine izin verir. Nano parçacıklar atomların \%20'sini yüzeyinde taşırlar bu durum onları 1sı iletimi için hazır hale getirir. $\mathrm{Bu}$ alanda yapılan çalışmalarda; 1sı transferi uygulamalarında akışkanın ısıl iletkenliğini artırmak için, nano boyutta katı parçacıklar ile süspansiyonlar oluşturularak nanoakışkanlar teşkil edilmiş ve 1sı transferi artırılmaya çalışılmıştır. Nanoakışkanların diğer bir avantajı ise; çok küçük boyutlarından dolayı sıvıda mikro taşınımı ortaya çıkaran ve bundan dolayı 1S1 transferini artıran parçacık hareketliliğidir. Bu özelliklerinden dolayı nanoakışkanlar özellikle yüksek 1S1 ak1l1 yüzeylerden olan 1S1 transferi uygulamalarında olmak üzere, endüstri, tıp, uzay araştırmaları gibi birçok alanda uygulanabilmektedir (Kilic ve Ozcan, 2017).

Endüstride (askerî uygulamalarda ve uzay çalışmalarında) yüksek soğutma sağlayan optimum 1sı yönetim tekniklerinin başında jetle soğutma tekniği gelir. Çarpmalı jetler sağladıkları yüksek ısı transfer performansı ile mühendislik, bilim ve sanayinin birçok dalında yaygın bir metot olarak kullanılmaktadır. Çarpan jet, bir lüleden çıkan akışkanın yüzeye çarptırılması ile elde edilir ve 1sı/kütle transferinin artırılması için genellikle türbülanslı jet çarpmaları kullanılır. Jet çarpma tekniğini cazip hale getiren etken; dar (sınırl) bir yüzeyde yüksek 1s1 transferi sağlamasıdır. Bu yöntemde katı yüzeyler akışkan jetleri vasıtası ile soğutulur. Böylece, minimum akış miktarı ile çok yüksek oranlarda 1sı transferi gerçekleştirilebilir. Yüzey soğutmalarında kullanılan çarpma etkili hava jeti 
tekniğinde hava, basınçlı olarak soğutulması istenilen yüzeye püskürtülür. $\mathrm{Bu}$ amaçla çeşitli çaplarda memeler (nozul veya lüleler) kullanılmaktadır. Yüzeye çarpan hava yüzeyde yüksek 1s1 transfer katsayısı oluşturur. Jet çarpması akışkan ile yüzey arasında yüksek yerel 1sı transfer katsayısı elde edilmesinde kullanılmakta olup, 1sı transferinde önemli derecede artışlar elde edildiğinden enerji tasarrufu da sağlamaktadır. Birçok mühendislik uygulamalarında kullanılan jet çarpma tekniği uygulamada gaz türbinlerinin kanatçıklarının soğutulmasında, cam temperleme, metallerin 1sıl işlemlerinde, kâğıt ve tekstil ürünlerinin kurutulmasında, boya, gıda sanayi, mikroişlemcilerin soğutulmasında, ısıtma ve pişirme amaçlı işlemlerde kullanılmaktadır (Isman vd., 2008).

Nanoteknolojinin biyolojik sistemlerde kullanılması özellikle insan benzeri sistemlerde (robotik, sibernetik) ya da insan uzuvlarının yerine kullanılacak sistemlerin geliştirilmesinde önemli bir adım olacaktır. Bu kapsamda; biyolojik sistemlerde hareketi sağlayan kas grupları genel olarak iki gruptan teşkil edilmiştir. Bir grup kasılma hareketi yaparken bir grupta gevşeme hareketi yaparak uzvun hareketini gerçekleştirir. Bu kasılma ve gevşeme hareketleri o kadar hassas bir şekilde gerçekleştirilir ki hareket sonunda ilgili kas grubu başlangıç noktası olan (set point) konuma geri döner. Günümüzde bu kas gruplarının görevini yapacak olan eyleyici mekanizmaları, elektromekanik, akışkan basıncı, mekanik, akıllı malzemeler ve hibrit sistemler olmak üzere beş alt gruptan oluşmaktadır. $\mathrm{Bu}$ gruplardan; akıllı malzemeler içerisinde yer alan şekil hafızalı alaşımlar ya da akıllı alaşımlar olarak bilinen şekil bellekli alaşımlar, uygulanan gerilmeye veya sıcaklık değişimine bağlı olarak 1sıl işlemle verilen ilk şekline dönebilen malzemelerdir. NiTi, NiTiHf, CuZnAl, NiMnGa gibi alaşımlar bu şekil hafızalı alaşımlara örnektir. Bu malzemelerin iki temel özelliği vardır. Birincisi; sıcaklık değişimi ile görülen tek veya çift yönlü şekil bellek özelliğidir. Diğer özelliği ise; malzeme üzerine uygulanan gerilmenin kaldırılması ile elde edilen süperelastik özelliktir. Martenzitik faz dönüşümü, sonucu elde edilen yüksek sıcaklık fazındaki (östenid 
fazdaki) malzeme üzerine bir gerilim uygulandığında, gerilimden dolayı faz dönüşümü meydana gelmekte ve yük kaldırıldığında alaşım ilk şekline geri dönmektedir. NiTi şekil bellekli alaşımlar \%8'lere varan birim şekil değiştirmeleri absorbe edecek yetenektedir. Bu özellik, havacılık ve uzay, biyomedikal alanında kalp stentleri, endodontik, ortodontik ve implant uygulamalarında oldukça yoğun olarak kullanılmaktadır (Dilibal, 2016).

Şekil 1'de şekil bellekli malzemelerin 1s1 verilmesi ve soğutulması durumundaki davranışı ve Şekil 2'de ekstensör ve flaksör hareketlendiricilere 1S1 verilmesi ve soğutulması durumunda parmağın hareketi ve Şekil 3'de bütün bir el prototipi sunulmuştur.

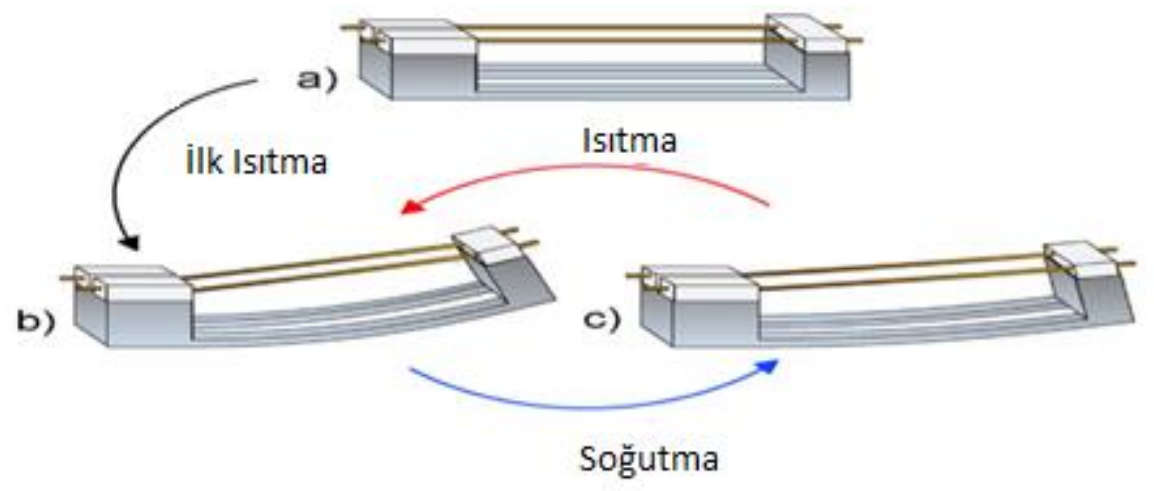

Şekil 1. Şekil bellekli malzemelerin 1sıl davranışı (Dilibal, 2016).

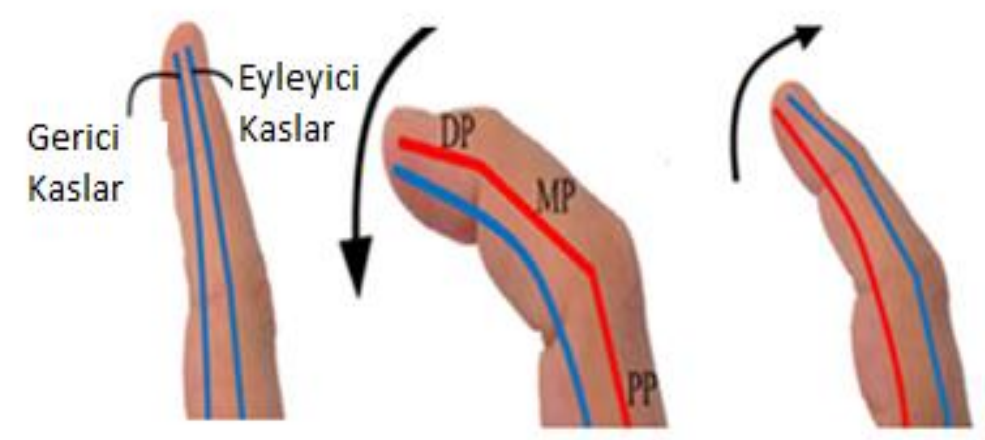

Şekil 2. Gerici ve eyleyici hareketlendiriciler ile parmağın kontrolü (Dilibal, 2016). 


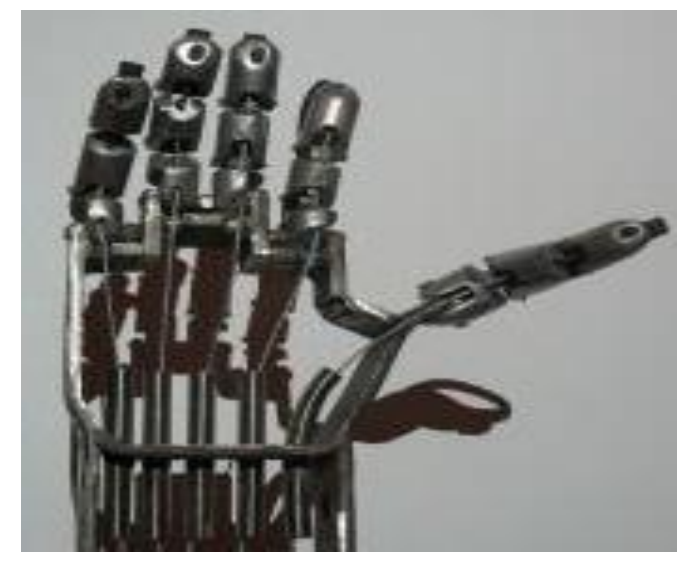

Şekil 3. Bütün bir el modeli (Dilibal, 2016).

$\mathrm{Bu}$ çalışmanın amacı; askerî sistemlerin robotik uygulamalarında (siber sistemler vb.) kullanılacak biyolojik sistemlerde farklı tipte nanoakışkanlar ve çarpan akışkan jet kullanılarak ısı transferinin ve akış özelliklerinin incelenmesidir. $\mathrm{Bu}$ maksatla; protez bir elin işaret parmağını simüle eden bakır bir plakadan olan 1S1 transferinin iyileştirilmesinde çarpmalı akışkan jetlerin ve farklı tipteki nanoakışkanların etkisi belirlenmeye çalışılmıştır. Böylece 1s1 transferinin iyileştirilmesi maksadıyla,

a. Farklı Reynolds sayılarının $(\operatorname{Re}=2000,4000,6000,8000)$,

b. Farklı nanoakışkanların $\left(\mathrm{Cu}-\mathrm{H}_{2} \mathrm{O}, \mathrm{CuO}-\mathrm{H}_{2} \mathrm{O}, \mathrm{TiO}_{2}-\mathrm{H}_{2} \mathrm{O}, \mathrm{Al}_{2} \mathrm{O}_{3^{-}}\right.$ $\left.\mathrm{H}_{2} \mathrm{O}\right)$ 1s1 transferine olan etkisi incelenmiştir.

$\mathrm{Bu}$ çalışma kapsamında; protez bir kolun işaret parmağı üzerinde oluşan 1sıl yükler ve bunların nanoakışkanlar yardımıyla soğutulması öngörülmüştür. Bu projede sağlık sektöründe ve ileride robotik uygulamalarda kullanılabilecek olan, protez bir kolun kontrolüne ilişkin 1sıl yönetiminin nasıl sağlanacağı ile ilgili bilgi alt yapısı oluşturulmuştur ve bundan sonraki çalışmalara kaynak teşkil edebilecektir. Nanoakışkanlar, geleneksel soğutucu akışkanlara göre sahip oldukları üstün özellikler sebebiyle gelecekte birçok alanda (askerî elektronik 
sistemlerin soğutulması, uzay çalışmalar, robotik uygulamalar vb.) kullanılacak olması sebebiyle büyük önem taşımaktadır. Literatürdeki nanoakışkanlar ve çarpan jetlere ilişkin çalışmalar incelendiğinde; Teamah vd. (2015) $\mathrm{Al}_{2} \mathrm{O}_{3}$ nanoakışkanının düz bir plakaya çarptırılması ile oluşan ısı transferini ve akış yapısını sayısal ve deneysel olarak farklı Reynolds sayılarında $(\mathrm{Re}=3000-32000)$ ve nanoakışkan hacim oranlarında $(\phi=\% 0-10)$ incelemiştir. Akışkan içindeki nanopartikülleri artırdıkça, akışkan olarak yalnız suyun kullanıldığı duruma göre yüzeyden olan 1S1 transferinin arttı̆ğ, 1sı transfer katsayısında \%62 oranında bir artış sağlanabildiği, akışkan olarak $\mathrm{CuO}$ kullanıldığında; 1sı transferinde $\mathrm{Al}_{2} \mathrm{O}_{3}$ nanoakışkanı kullanılma durumuna göre \%8,9 ve $\mathrm{TiO}_{2}$ nanoakışkanı kullanılma durumuna göre \%12 oranında bir artış sağlanabildiği görülmüştür. Manca vd. (2016) saf su ve su/ $\mathrm{Al}_{2} \mathrm{O}_{3}$ nanoakışkanı kullanıldığı durumda, sınırlandırılmış çarpan jetlerin sabit 1sı akılı düz bir plakadan olan 1sı transferine etkisini incelemiştir. Jet Reynolds sayısı $(\operatorname{Re}=100-400)$ ve boyutsuz kanal yüksekliği $(H / W=4-10)$ çalışmada kullanılan parametrelerdir. Reynolds sayısı ve akışkan içerisindeki partikül konsantrasyonu arttıkça yerel 1sı transfer katsayısının ve Nusselt sayısının arttı̆̆ı, ortalama 1S1 transfer katsayısındaki en yüksek artışın (\%36) H/W=10 ve nanoakışkan hacim oranlarının $\phi=\% 5$ olduğu durumda elde edildiği ifade edilmiştir. Chien vd. (2003) düz plaka 1sı borusunda nanoakışkan uygulamasını deneysel olarak incelemiştir. Nanoakışkan kullanımı ile 1sıl dirençte saf su kullanımına göre \%40 azalma sağlanabildiği tespit edilmiştir. Sun vd. (2016) CuO nanoakışkanı kullanılan tek bir çarpan jetin 1S1 transferine etkisini incelemiştir. Nanoakışkan kullanıldığında yalnızca su kullanılması durumuna göre 1S1 transferinde önemli bir artış sağlanabildiği, basınç düşüşünde önemli bir değişim olmadığı, dairesel nozul kullanıldığında, kare şekilli nozula göre daha yüksek 1Sı transfer katsayısı elde edildiği, jet açısı $90^{\circ}$ olduğunda en yüksek 1sı transferinin elde edildiği belirlenmiştir. Kang vd. (2006) gümüş nanoparçacıklar ve saf su kullanarak teşkil ettikleri nanoakışkan ile yaptıkları deneysel çalışmada; saf su kullanımına göre 10 
$\mathrm{nm}$ nanoparçacıklar kullanıldığında 1 sıl dirençte $\% 50$ ve $35 \mathrm{~nm}$ çaplı nanoparçacıklar kullandıklarında \%80 oranında azalma olduğunu belirlemiş̧lerdir. Shang vd. (2007) çalışmasında Cu-su nanoakışkanı ile kapalı devre titreşimli bir ısı borusunun 1sı transferi özelliklerini incelemiştir. Saf su ile karşılaştırıldığında bu nanoakışkanın kullanıldığı durumda sistemin 1sı aktarma kapasitesinin \%83 oranında artırılabildiği görülmüştür. Umer vd. (2015) çalışmasında; CuO-su nanoakışkanı kullanarak laminer akış şartlarında sabit 1sı akılı bir yüzeyden olan 1sı transferini faklı hacimsel oranlarda incelemişlerdir. Sonuç olarak parçacık hacim oranı arttıkça ve Reynolds sayısı arttıkça 1Sı transfer katsayısının da arttığı, 1S1 transfer katsayısındaki en yüksek artışın (\%61) parçacık hacim oranı \%4 ve Reynolds sayısı $\mathrm{Re}=605$ olduğu durumda gerçekleştiği tespit edilmiştir. Qu vd. (2010) nanoakışkan olarak $\mathrm{Al}_{2} \mathrm{O}_{3}$-su kullandıkları deneysel çalışmalarında kapalı devre titreşimli 1sı borusunun 1sıl performansını incelemişlerdir. Sonuç olarak sistem 1sıl direncinin saf su kullanımına göre \%32,5 azaldığını tespit etmişlerdir. Kilic ve Ozcan (2017) yüksek 1s1 akılı bir yüzeyden olan 1s1 transferini farklı nanoakışkanlar ve çoklu jetler için incelemişlerdir. Re sayısındaki artışın ve parçacık çapındaki azalmanın 1sı transferinde artışa sebep olduğunu, $\mathrm{Cu}$-su nanoakışkanı kullanma durumunda, $\mathrm{Al}_{2} \mathrm{O}_{3}$-su nanoakışkanına göre \%9,3 ve TiO-su nanoakışkanına göre \%8,4 artış sağlanabildiğini tespit etmişlerdir. Yan vd. (2005) çalışmasında; kanal akışı ile jet akışının birlikte uygulandığı durumda 1sı transferi incelenmiştir. Çalışma deneysel bir çalışmadır. Kanal akışında Re=10000-40000 aralığında, jet akışında $\operatorname{Re}=5000-20000$ aralığındadır. Sonuç olarak; hat şeklindeki aksial kanatçıkların uygulanması durumunda kanatçıkların olmama durumuna göre \%50-\%90 lık bir artış olduğu, çarpmalı jetin uygulanmasının kanal akışına göre 1sı transferini artırdığı tespit edilmiştir. Genel olarak geçirgen köpük kullanılmasının 1S1 transferini artırdığı, bu durumun Re sayısı arttıkça daha da arttığı, geçirgen köpük kullanıldığında kanatçıkların kullanılma durumuna göre daha fazla basınç kaybı olduğu ancak 1sı transferini artırdığı tespit edilmiştir. Kilic vd. (2017) sabit 
1S1 akılı düz bir plakanın çarpan akışkan hava jeti yardımı ile soğutulmasını farklı Reynolds sayıları ve boyutsuz kanal yükseklikleri için incelemiştir. Ortalama Nusselt sayısının $\mathrm{Re}=4000-10000$ aralığında $\% 49,5, \mathrm{H} / \mathrm{D}_{\mathrm{h}}=4-10$ aralığında ise, \%17,9 oranında arttığı tespit edilmiştir. Isman vd. (2008) çalışmasında; sabit yüzey 1sı akısına sahip sınırlandırılmamış bir plakanın bir tek çarpmalı jet ile soğutulması incelenmiştir. Çalışma sayısal bir çalışmadır. Akışkanın türbülanslı, iki boyutlu ve sürekli halde olduğu kabulü yapılmıştır. RNG ve standart $\mathrm{k}-\varepsilon$ modelinin diğer modellere göre daha iyi yakınsadığı ifade edilmiştir. Re sayısı 4000-12000 ve nozul plaka mesafesinin-nozul çapına oranı 4-10 aralığında alınmıştır. Sonuç olarak; Re sayısı artırılarak ya da nozul-plaka mesafesi azaltılarak 1s1 transferinin artırılabileceği tespit edilmiştir. McGuinn vd. (2007) çalışmasında; iki ayrı çıkış geometrisine sahip (düz çıkışlı ve şekil verdirilmiş) nozuldan oluşturulan akışın sağladığı 1sı transferi incelenmiştir. Çalışma sayısal ve deneysel bir çalışmadır. Çalışma sonucunda; şekil verdirilmiş nozulun düz nozula göre daha etkin bir 1S1 transferi sağladığı gözlenmiştir. Yüzeydeki 1s1 transferinin yalnızca oluşan türbülanslara bağlı olmadığı aynı zamanda yüzeye gelen akış geometrisine de bağlı olduğu tespit edilmiştir. Dilibal (2016) çalışmasında; NiTi şekil bellekli malzeme kullanılarak üretilen robotik bir parmağı incelemiş ve sonuç olarak; NiTi şekil bellekli alaşımların zıt yönlü kullanma tekniği ile insansız su altı araçları, robot gripper sistemleri, mayın impa, su altı kesme ve arama kurtarma çalışmalarında kullanılabileceğini öngörmüştür.

$\mathrm{Bu}$ çalışmanın literatürde yer alan çalışmalardan temel farklılıkları ise şu şekilde özetlenebilir; bugün için, nanoakışkanlar alanında yapılan akademik çalışmalar son derece kısıtlıdır. Hatta nanoakışkanların sosyal hayatta uygulamalarına yönelik çalışmalar yok denecek kadar azdır. Bu nedenle bu çalışma nanoakışkanların biyolojik sistemlerde kullanılmasına yönelik öncü çalışmalardan birisi olacaktır. Literatürde nanoakışkanlar (sınırlı sayıda) ve çarpan jetlere yönelik ayrı ayrı çalışmalar mevcut olmasına rağmen; nanoakışkanların çarpan jet tekniği 
ile kullanılmasına yönelik çalışma yok denecek kadar azdır. Bu çalışma ile kazanılan bilgi altyapısı sayesinde; uzuv kaybına uğramış kişilerin (başta gaziler ve kaza sonucu meydana gelen) hayatlarını daha kaliteli bir şekilde sürdürmelerine sebep olacak protez kolun isıl kontrolünün ve üretiminin sağlanması hedeflenmiştir.

\section{Sayisal Model ve Matematiksel Formülasyon}

$\mathrm{Bu}$ çalışmada, askerî sistemlerde karşılaşılan önemli problemlerden olan yüksek 1S1 akılı bir yüzeyden olan 1sı transferinin, nanoakışkanların çarpan akışkan jet tekniği ile kullanılarak iyileştirilmesi sayısal olarak incelenmiştir. Hedef plaka boyutlar1 90x15x2 mm (boy x genişlik x yükseklik) olarak modellenmiştir. x-y düzlemi üzerine yerleştirilmiş plakanın yüzeyindeki sabit 1S1 akısı 222000 $\mathrm{W} / \mathrm{m}^{2}$ 'dir. Nozul hidrolik çapı $\mathrm{D}_{\mathrm{h}}=3,5 \mathrm{~mm}$ 'dir. Bu sayısal analiz için PHOENICS HAD programının düşük Re sayılı k-E türbülans modeli kullanılmıştır. Bu model; sınırlandırılmış çarpan jet uygulamalarında, duvar etkilerini de dâhil etmesi ve uygulanan Reynolds değerinde, deney sonuçları ile uyumlu sonuçlar elde edilebilmesi sebebiyle tercih edilmiştir (Kilic vd., 2017, McGuinn vd., 2007). Hedef plaka boyu $90 \mathrm{~mm}$ ve kalınlığı $2 \mathrm{~mm}$ 'dir. Tüm plaka alttan sabit 1sı akısıyla 1sıtılmaktadır. Hedef plakaya verilen tüm ısının iletimle plaka yüzeyine ulaştığı ve plaka yüzeyinin taşınımla soğutulduğu öngörülmüştür. Dolayısı ile iletim denklemi de çözülmüştür. Akışkan sıkıştırılamaz akışkandır. Sayısal olarak incelenen modelin geometrisi Şekil 4'de ve hücre yapısı Şekil 5'de gösterilmiştir. Kütlenin korunumu, momentum ve enerji denklemlerine uygun sınır şartları verilerek oluşturulan model sürekli şartlarda olup, çevreye radyasyon ile olan 1sı transferi ihmal edilmiş, sadece türbülanslı, zorlanmış taşınımla olan 1S1 transferi dikkate alınmıştır. Ayrıca jet giriş sıcaklığı $\mathrm{T}_{\mathrm{j}}=20^{\circ} \mathrm{C}$ olarak modellenmiştir. Modelde kullanılan sınır şartları Tablo 1.'de sunulmuştur. 


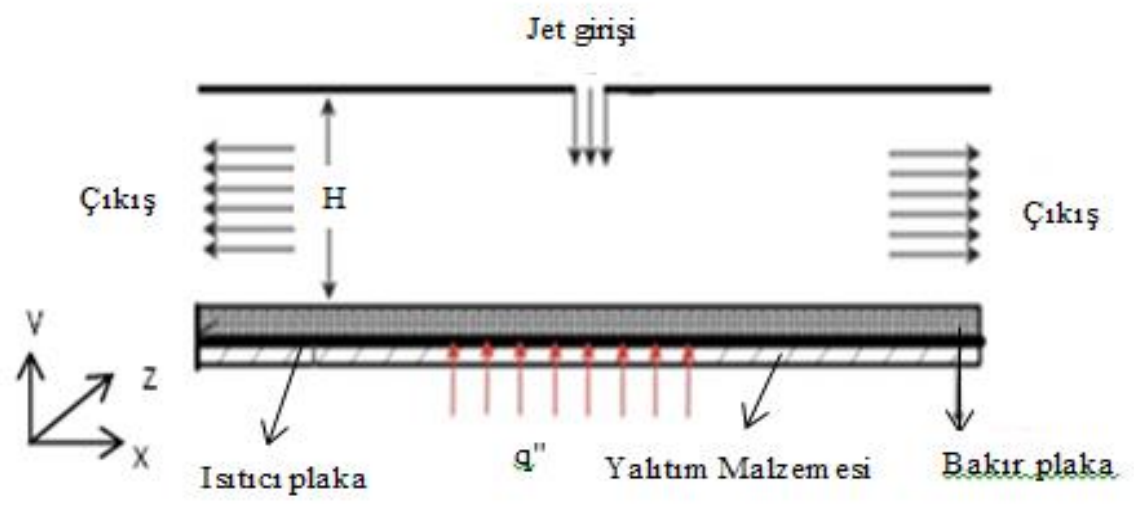

Şekil 4. HAD Model Geometrisi

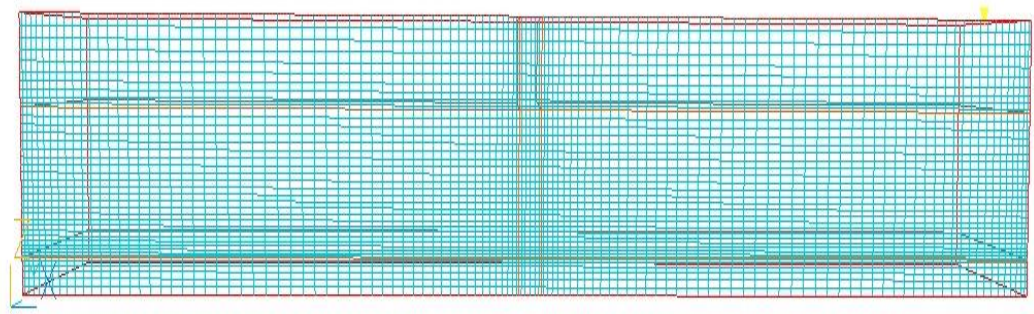

Şekil 5. Hücre Yapıs1

Tablo 1. Sınır Şartları (Kilic ve Başkaya, 2017)

\begin{tabular}{|l|l|l|l|l|l|c|}
\hline & $\mathrm{U}(\mathrm{m} / \mathrm{s})$ & $\mathrm{V}(\mathrm{m} / \mathrm{s})$ & $\mathrm{W}(\mathrm{m} / \mathrm{s})$ & $\mathrm{T}(\mathrm{K})$ & $\begin{array}{c}\mathrm{k} \\
(\mathrm{J} / \mathrm{kg})\end{array}$ & $\begin{array}{c}\varepsilon \\
(\mathrm{J} / \mathrm{kg} . \mathrm{s})\end{array}$ \\
\hline Jet & $\mathrm{U}=0$ & $\mathrm{~V}=0$ & $\mathrm{~W}=\mathrm{W}_{\text {giriş }}$ & $\mathrm{T}=\mathrm{T}_{\text {giriş }}$ & $\left(T_{\mathrm{I}} W_{\text {jet }}\right)$ & $\left(C_{\mu} C_{d}\right)^{3 / 4} k^{3}$ \\
\hline Plaka & $\mathrm{U}=0$ & $\mathrm{~V}=0$ & $\mathrm{~W}=0$ & $\mathrm{q}^{\prime \prime}=\mathrm{q}_{\text {yüzey }}$ & $\mathrm{k}=0$ & $\frac{\partial \varepsilon}{\partial z}=0$ \\
\hline Çıkış & $\frac{\partial U}{\partial x}=0$ & $\frac{\partial V}{\partial x}=0$ & $\frac{\partial W}{\partial x}=0$ & $\mathrm{~T}=\mathrm{T}_{\text {çiks }}$ & $\frac{\partial k}{\partial x}=0$ & $\frac{\partial \varepsilon}{\partial x}=0$ \\
\hline $\begin{array}{l}\text { Ön } \\
\text { Duvar }\end{array}$ & $\mathrm{U}=0$ & $\mathrm{~V}=0$ & $\mathrm{~W}=0$ & $\frac{\partial T}{\partial y}=0$ & - & - \\
\hline $\begin{array}{l}\text { Üst } \\
\text { Duvar }\end{array}$ & $\mathrm{U}=0$ & $\mathrm{~V}=0$ & $\mathrm{~W}=0$ & $\frac{\partial U}{\partial z}=0$ & - & - \\
\hline
\end{tabular}


Süreklilik, türbülanslı momentum ve enerji denklemleri aşağıda sunulmuştur.

Süreklilik denklemi:

$$
\frac{\partial U_{i}}{\partial x_{i}}=0
$$

Momentum denklemi:

$$
\rho U_{i} \frac{\partial U_{j}}{\partial x_{i}}=-\frac{\partial P}{\partial x_{j}}+\frac{\partial}{\partial x_{i}}\left[\mu\left(\frac{\partial U_{i}}{\partial x_{j}}+\frac{\partial U_{j}}{\partial x_{i}}\right)-\rho \overline{u_{i}^{\prime} u_{j}^{\prime}}\right]
$$

Enerji denklemi:

$$
\rho c_{p} U_{i} \frac{\partial T}{\partial x_{i}}=\frac{\partial}{\partial x_{i}}\left[k \frac{\partial T}{\partial x_{i}}-\rho c_{p} \overline{u_{i}^{\prime} T^{\prime}}\right]
$$

Düşük Reynolds Sayılı k-E Türbülans modelinde kullanılan modelden kaynaklanan aktarım denklemleri ise;

$$
\begin{gathered}
\rho U_{i} \frac{\partial k}{\partial x_{i}}=\frac{\partial}{\partial x_{i}}\left[\left(\mu+\frac{\mu_{t}}{\sigma_{k}}\right) \frac{\partial k}{\partial x_{i}}\right]+\mu_{t}\left(\frac{\partial U_{i}}{\partial x_{j}}+\frac{\partial U_{j}}{\partial x_{i}}\right) \frac{\partial U_{i}}{\partial x_{j}}-\rho \varepsilon \\
\rho U_{i} \frac{\partial \varepsilon}{\partial x_{i}}=\frac{\partial}{\partial x_{i}}\left[\left(\mu+\frac{\mu_{t}}{\sigma_{\varepsilon}}\right) \frac{\partial \varepsilon}{\partial x_{i}}\right]+f_{1} C_{1} \mu_{t} \frac{\varepsilon}{k}\left(\frac{\partial U_{i}}{\partial x_{j}}+\frac{\partial U_{j}}{\partial x_{i}}\right) \frac{\partial U_{i}}{\partial x_{j}}-f_{2} C_{2} \rho \frac{\varepsilon^{2}}{k}
\end{gathered}
$$

Türbülans kinetik vizkozitesi ise;

$$
\mu_{t}=f_{\mu} C_{\mu} \rho \frac{k^{2}}{\varepsilon}
$$

Burada $\sigma_{k}$ ve $\sigma_{\varepsilon}$ değerleri k ve $\varepsilon$ 'un Türbülans Prandtl sayılarıdır. $C_{\mu}, C_{1 \varepsilon}$ ve $C_{2 \varepsilon}$ değerleri ise modelde kullanılan ampirik değerlerdir. Katsayıların değerleri aşağıda sunulmuştur.

$$
\sigma_{k}=1.00 \quad \sigma_{\varepsilon}=1.314 \mathrm{C}_{1}=1.44 \quad \mathrm{C}_{2}=1.92 C_{\mu}=0.09
$$

Yüzeyden konveksiyonla olan 1sı transferi;

$$
Q_{\text {tasnm }}=h \cdot A \cdot \Delta T
$$

Burada $h$ 1sı taşınım katsayısı, $A$ taşınım yüzey alanı, $\Delta T\left(\Delta T=T_{\text {yüzey }}-T_{\text {yigin }}\right)$ plaka yüzey sıcaklığı (hedef plakanın x-y düzlemi orta hattından belirlenen yüzey 
sıcaklığıdır) ile yığın sıcaklı̆̆g (akışkan sıcaklığı ile plaka yüzey sıcaklığının aritmetik ortalamasıdır) arasındaki farktır.

Nusselt sayısı $(\mathrm{Nu})$; taşınımla olan 1s1 transferinin iletimle olan 1s1 transferine oranını gösteren boyutsuz parametredir. Yerel Nusselt sayısı x-y ekseni boyunca hedef plakanın tam ortasından alınmıştır. Böylece Y eksenindeki sıcaklık farkları minimize edilmiştir. Nusselt sayısı (Kilic ve Başkaya, 2017);

$$
N u=\frac{\left(q_{\text {tasnm }} D_{h}\right.}{\left(T_{\text {yüzey }}-T_{\text {yigin }}\right) k_{n f}}
$$

Burada $T_{\text {yüzey }}$ yüzey sıcaklığı, $\mathrm{q}_{\mathrm{tasnm}}$ birim yüzey alanı için $1 \mathrm{~s} 1$ akısı, $D_{h}$ hidrolik çap ve $k_{n f}$ ise nanoakışkan ısıl iletkenlik katsayısıdır.

Reynolds sayısı $(R e)$; zorlanmış taşınımda akışın laminer veya türbülanslı olup olmadığını belirlemek için kullanılmaktadır. Çarpan jetler için türbülanslı akışa geçiş değeri $\mathrm{Re}=1000$ 'dir ( $\mathrm{Li}$ ve Zhou, 2007). Bu sebeple numerik çalışmada türbülans modeli kullanılmıştır. Reynolds sayısı ise;

$$
\operatorname{Re}=\frac{\left(\rho_{n f} \cdot V_{j e t} \cdot D_{h}\right)}{\left(\mu_{n f}\right)}
$$

Burada $\rho_{n f}$ nanoakışkan yoğunluğu, $V_{\text {jet }}$ jet çıkış hızı ve $\mu_{n f}$ nanoakışkan dinamik vizkozitesidir. Nanoakışkan yoğunluğu ise (Teamah vd., 2015);

$$
\rho_{n f}=(1-\varphi) \cdot \rho_{b f}+\varphi \cdot \rho_{p}
$$

Burada $\rho_{b f}$ temel akışkan (su) yoğunluğu, $\varphi$ nanoakışkan hacimsel oranı, $\rho_{p}$ ise nanoakışkan içerisindeki katı parçacıkların yoğunluğudur. Nanoakışkan hacimsel oranı ise (Teamah vd., 2015);

$$
\varphi=\frac{1}{(1 / \omega) \cdot\left(\rho_{p}-\rho_{b f}\right)}
$$

Burada $\omega$ nanoakışkan ile temel akışkanın (su) yoğunlukları arasındaki farktır. Nanoakışkan özgül ısısı ise (Manca vd., 2016); 


$$
C_{p_{n f}}=\frac{\vartheta \cdot\left(\rho \cdot C_{p}\right)_{p}+(1-\vartheta) \cdot\left(\rho \cdot C_{p}\right)_{f}}{\left(\rho_{n f}\right)}
$$

Burada $C_{p}$ parçacığın özgül 1sısı, $C_{p(f)}$ temel akışkanın özgül 1sısıdır. Nanoakışkanın 1 sıl iletim katsayısı ise (Corcione, 2011);

$$
\frac{k_{e f f}}{k_{f}}=1+4.4 \operatorname{Re}_{(p)}{ }^{0.4} \operatorname{Pr}^{0.66}\left(\frac{T}{T_{f r}}\right)^{10}\left(\frac{k_{p}}{k_{f}}\right)^{0.03} \varphi^{0.66}
$$

Burada $\operatorname{Re}_{(p)}$ nanoparçacık Reynolds sayısı, $\operatorname{Pr}$ temel akışkanın Prandtl sayısı. $k_{p}$ nanoparçacıkların 1sıl iletim katsayısı, $\varphi$ parçacık hacimsel oranı, $T$ nanoakışkanın sıcaklığı $(\mathrm{K}), T_{f r}$ temel akışkanın donma sıcaklığıdır. Nanoparçacık Reynolds sayıs ise (Corcione, 2011);

$$
R e_{p}=\frac{2 \rho_{f} k_{b} T}{\pi \mu_{f}^{2} d_{p}}
$$

$K_{b}$ Boltzmann's sabitidir. Nanoakışkanın dinamik vizkozitesi ise şu şekilde hesaplanmıştır (Corcione, 2011).

$$
\mu_{\mathrm{nf}}=\mu_{\mathrm{bf}}\left(1+2,5 \varphi+4,698 \varphi^{2}\right)
$$

Nanoakışkanların thermofiziksel özellikleri (nano akışkan yoğunluğu, 1S1 iletim katsayıs1, özgül 1sıs1, kinematik vizkozitesi, 1sıl yayılma katsayıs1 yukarıda sunulan formüller kullanılarak belirlenmiş ve nanoakışkan özellikleri olarak programa girilmiştir. Müteakiben sınır şartları tanımlanmış ve program çalıştırılarak, sayısal sonuçlar elde edilmiştir.

\section{Sayısal Sonuçların Doğrulanması}

Bu çalışmada; PHOENICS Hesaplamalı Akışkanlar Dinamiği programının Düşük Reynolds Sayılı k-E Türbülans modeli kullanılmıştır. Bu model çalışmada kullanılan Reynolds sayıları aralığında duvar etkilerini de doğru şekilde modelleyebildiği öngörüldügünden tercih edilmiştir. Bu modelde model geometrisi sonlu elemanlar metodu kullanılarak ayrıştırılır ve hücrelere bölünür. Her hücre 
için süreklilik, momentum ve enerji denklemleri çözülerek model sonuçlarındaki hata değeri istenen hata değerinin altında olana kadar (model sonuçları yakınsayana kadar) hesaplamalar tekrarlanır. Hata değerleri belli hata kıstasının altına ininceye kadar ve noktasal değerler anlık olarak değişmeyene kadar model çalıştırılarak sayısal sonuçlar elde edilir. $\mathrm{Bu}$ modelleme çalışmasında 96x15×34 hücre kullanılmıştır. Modelde kullanılan hücre yapısı akış şartlarına göre düzenlenmiştir. Model sonuçlarında daha hassas sonuçlar alabilmek için; jet girişinde, plaka yüzeyinde, hücre yoğunluğu artırılmıştır. Tekrar (süpürme) sayıs1 400-2500 arasında ve hücre sayısı 20-55 arasında çalışılmıştır. Tekrar sayısı; modelin yakınsaması için ya da hata değerinin belli bir değerin altında olması için her nokta için hesaplamaların kaç kez tekrarlanacağını ifade eder. Model sonuçlarının; tekrar

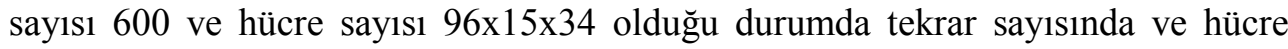
sayısından bağımsız olduğu gözlemlenmiştir. Ayrıca bağımsız duvar mesafesi hedef plaka yüzeyinde ve kanal duvarlarında 2,5 (programda öngörülen yakınsama kriteri) değerinin altındadır. Sayısal model, Li vd. (2012) yapmış olduğu deney sonuçları ile karşılaştırılmıştır. Şekil 6'da görüldüğü üzere sayısal model ve deneysel sonuçlar arasındaki fark $\mathrm{Re}=8000$ için \%15'in altındadır. Mevcut çalışmada Reynolds değerleri 2000-8000 arasındadır.

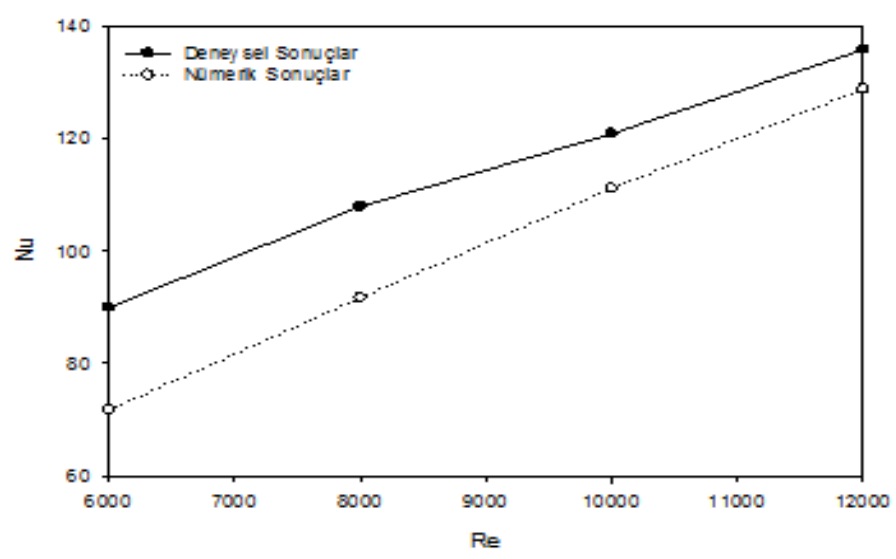

Şekil 6. Modelin deneysel sonuçlarla doğrulanması 


\section{Bulgular ve Tartışma}

Bu bölümde; farklı Reynolds sayılarının $(\mathrm{Re}=2000,4000,6000,8000)$ ve farklı tiplerde hazırlanan nanoakışkanların $\left(\mathrm{Cu}-\mathrm{H}_{2} \mathrm{O}, \mathrm{CuO}-\mathrm{H}_{2} \mathrm{O}, \mathrm{TiO}_{2}-\mathrm{H}_{2} \mathrm{O}, \mathrm{Al}_{2} \mathrm{O}_{3}\right.$ $\mathrm{H}_{2} \mathrm{O}$ ve saf su için) 1sı transferine etkisi sayısal olarak incelenmiştir.

\section{Farklı Reynolds Sayılarının $(\operatorname{Re}=2000,4000,6000,8000)$ Etkisi}

Genel olarak Re sayısı arttıkça sıcaklık değerlerinin düştügü ve yerel Nu sayısının arttığı görülmüştür. Re sayıs1 4000-8000 aralığında artırıldığında $\mathrm{Nu}_{\text {ort }}$ sayısında \%47,2'lik bir artış elde edilebildiği görülmüştür. Re sayısı arttıkça model sonuçlarının deney sonuçlarından daha fazla farklılık gösterdiği tespit edilmiştir. Bunun sebebinin seçilen modelin özellikle çarpma noktasında oluşan yüksek türbülanslı akışı tam olarak modelleyememesi olarak değerlendirilmektedir. $\mathrm{Bu}$ durum daha önceki deney sonuçları ile (Kilic ve Baskaya, 2017) karşılaştırıldığı durumla da benzerlik göstermektedir. Böylece yapılan çalışmanın (elde edilen sonuçların) tutarlı olduğu değerlendirilebilir. Farklı Re sayılarının yerel Nusselt sayısına etkisi Şekil 7'de sunulmuştur.

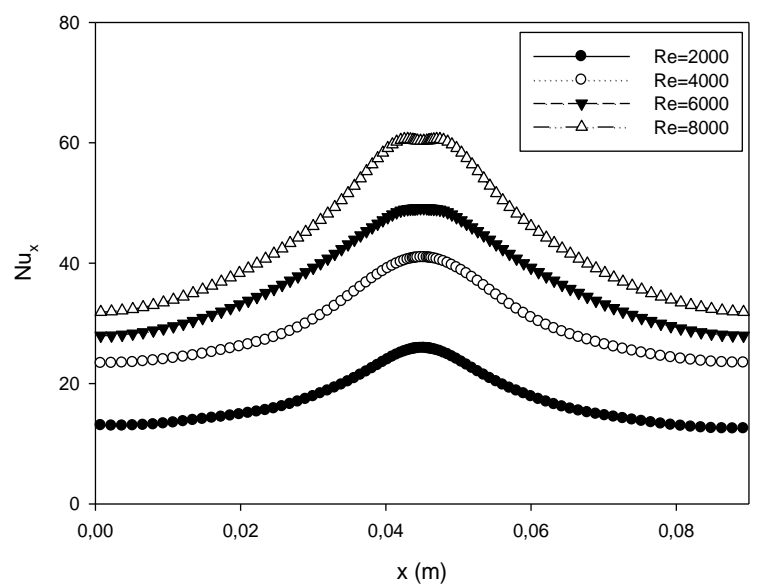

Şekil 7. Farklı Re sayılarının yerel Nusselt sayısına etkisi 
Re sayısı arttıkça çarpan jetlerin yerel soğutma özelliğinin daha belirgin bir şekilde gözlemlenebildiği tespit edilmiştir. Böylece, duvar jeti bölgesinde $\mathrm{x}$ mesafesi arttıkça azalan soğutma etkisinin istenen sıcaklığın altına düşülmesi durumunda, birden farklı (jetler arası en uygun mesafe tespit edilerek) jetin soğutma için kullanılabileceği değerlendirilmiştir. $R e=2000$ ve $R e=8000$ değerleri için elde edilen hız vektörleri Şekil 8-9'da sunulmuştur. Re sayısı artıkça çarpma noktasında oluşan girdapların jet etkisini azalttığı buna bağlı olarak çarpma noktasında duvar jeti bölgesine göre bir azalma olduğu ancak, akışkanın momentum transferine bağlı olarak hızlanan akışkanın duvar jeti bölgesinde daha belirgin bir şekilde hidrodinamik sınır tabakayı oluşturabildiği tespit edilmiştir. $\mathrm{Re}=2000-4000$ aralığında ortaya çıkan $\mathrm{Nu}_{\text {ort }}$ değerindeki artış $\mathrm{Re}=6000-8000$ aralığında ortaya çıkan değerden daha büyüktür. Bunun sebebinin akışkan hızındaki artışa bağlı olarak yüzeyde meydana gelen ayrılmalar olduğu değerlendirilmiştir.

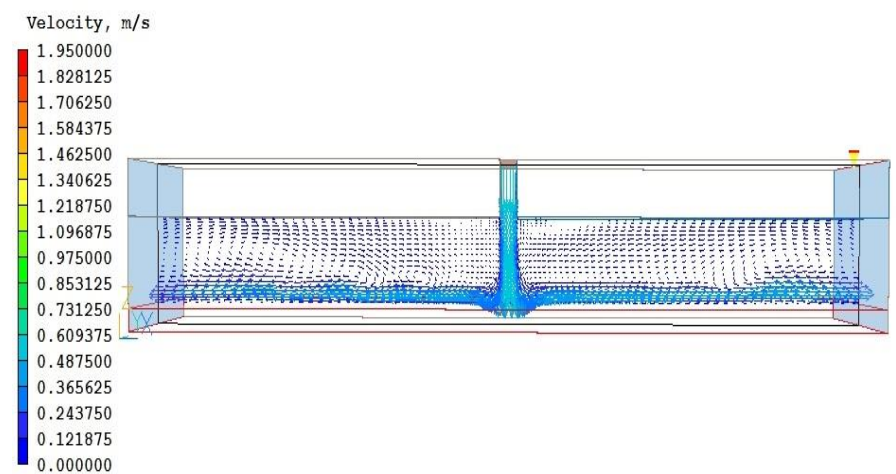

Şekil 8. Re=2000 için hız vektörleri 


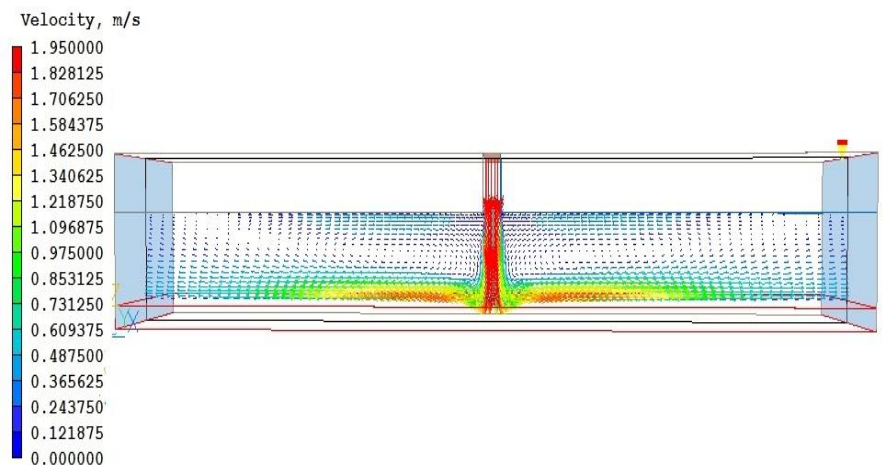

Şekil 9. $R e=8000$ için hız vektörleri

Re sayısı arttıkça yüzeyde oluşan sıcaklık azalmasının daha belirgin bir şekilde görülebildiği tespit edilmiştir. $\mathrm{Re}=2000$ değerinde akışkan hızı daha az olduğu için duvara yakın bölgelerde ve duvar jeti etkisinin azaldığı bölgelerde sıcaklık artışı belirgin olarak tespit edilmiştir. $\mathrm{Bu}$ sebeple bu değerin uygun soğutma için (yüzey sıcaklığının vücut sıcaklığı olan $37^{\circ} \mathrm{C}$ 'un altında olması) yeterli olmadığı tespit edilmiştir. $\mathrm{Re}=8000$ değerinde ise; yüzey sıcaklığındaki değişmelerin çarpma noktasına yakın bölgelerde daha belirgin bir şekilde oluştuğu tespit edilmiştir. Çarpma plakasının yüksek ısı iletim katsayısına sahip olan bakır bir plaka olduğu düşünüldügünde yerel olarak sıcaklığın bu şekilde düşürülebilmesi, şekil hafızalı bileşiklerle oluşturulacak sistemlerin ${ }_{1 s 1}$ kontrolünde etkin bir çözüm olabileceği değerlendirilmiştir. $R e=2000$ ve $R e=8000$ değerleri için elde edilen sıcaklık konturları Şekil 10-11'da sunulmuştur.

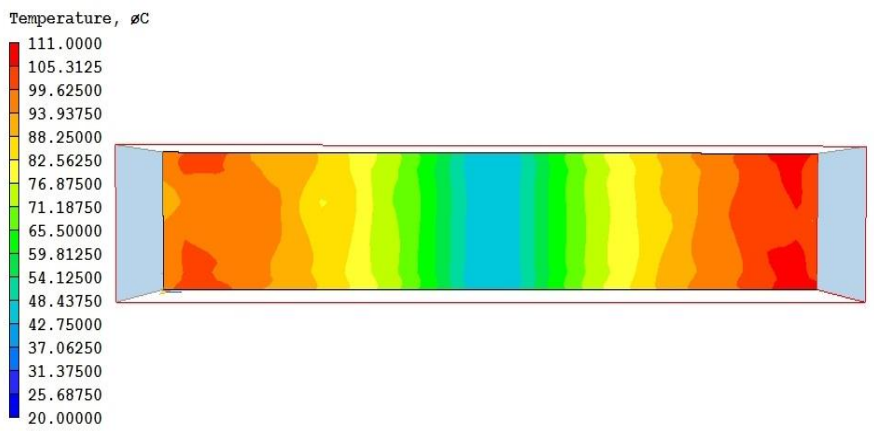

Şekil 10. $R e=2000$ için sıcaklık konturları 


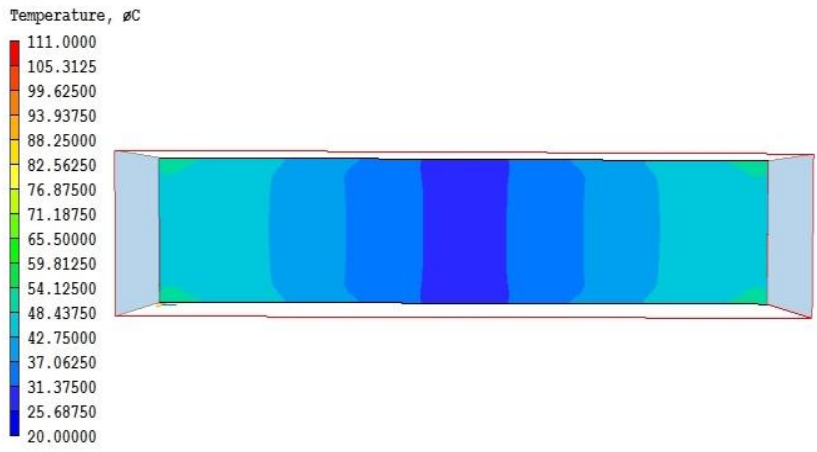

Şekil 11. $R e=8000$ için sıcaklık konturları

Farklı Nanoakışkanların $\left(\mathrm{Cu}-\mathrm{H}_{2} \mathrm{O}, \mathrm{CuO}-\mathrm{H}_{2} \mathrm{O}, \mathrm{TiO}_{2}-\mathrm{H}_{2} \mathrm{O}, \mathrm{Al}_{2} \mathrm{O}_{3}-\mathrm{H}_{2} \mathrm{O}\right)$ Isı Transferine Olan Etkisi

$\mathrm{Cu}-\mathrm{H}_{2} \mathrm{O}$ nanoakışkanın en iyi 1sı transferi performansını gösterdiği tespit edilmiştir. $\mathrm{Bu}$ sonuç; $\mathrm{Cu}-\mathrm{H}_{2} \mathrm{O}$ nanoakışkanının en yüksek ısı iletim katsayısına sahip olması düşünüldügünde son derece tutarlı bir sonuçtur. Farklı tip nanoakışkanların termofiziksel özellikleri Tablo 2'de sunulmuştur.

Tablo 2. Nanoakışkanların Termofiziksel Özellikleri

\begin{tabular}{|l|c|c|c|c|c|}
\hline Nanoakışkan & Yoğunluk & Özgül Isı & $\begin{array}{c}\text { Kinematik } \\
\text { Vikozite }\end{array}$ & $\begin{array}{c}\text { Isı İletim } \\
\text { Katsayısı }\end{array}$ & $\begin{array}{c}\text { Isıl Yayılım } \\
\text { Katsayısı }\end{array}$ \\
\hline $\mathbf{C u}-\mathbf{H}_{\mathbf{2}} \mathbf{O}$ & 1157.43 & 3594.13 & 0,000000902 & 0,6422 & 0,0001544 \\
\hline $\mathbf{C u O}-\mathbf{H}_{2} \mathbf{O}$ & 1108.23 & 3754.31 & 0,000000943 & 0,6391 & 0,0001540 \\
\hline $\mathbf{T i O}_{\mathbf{2}}-\mathbf{H}_{\mathbf{2}} \mathbf{O}$ & 1063.24 & 3902.51 & 0,000000982 & 0,6382 & 0,0001537 \\
\hline $\mathbf{A l}_{\mathbf{2}} \mathbf{O}_{\mathbf{3}}-\mathbf{H}_{\mathbf{2}} \mathbf{O}$ & 1055.84 & 3931.45 & 0,000000989 & 0,6378 & 0,0001534 \\
\hline
\end{tabular}

Bunun yanı sıra, $\mathrm{Cu}-\mathrm{H}_{2} \mathrm{O}$ nanoakışkanı kullanılması durumunda, ortalama Nusselt sayısında (ortalama 1S1 taşınım katsayısı esas alınarak hesaplanan Nusselt sayısı değeridir) sırasıyla $\mathrm{CuO}-\mathrm{H}_{2} \mathrm{O}, \mathrm{TiO}_{2}-\mathrm{H}_{2} \mathrm{O}, \mathrm{Al}_{2} \mathrm{O}_{3}-\mathrm{H}_{2} \mathrm{O}$ ve saf suya göre $\% 2,6$, \%5,5, \%6,1, \%9,6 iyileşme olduğu gözlemlenmiştir. Ayrıca sayısal analizde kullanılan model değerlerinin deneysel sonuçlardan nanoakışkan kullanılması durumunda, saf su kullanılması durumuna göre daha fazla sapma gösterdiği tespit 
edilmiştir. Bunun sebebinin; nanoakışkan içindeki nano parçacıkların dönme ve öteleme hareketlerinin modellenmesindeki belirsizliğin büyüklüğünden kaynaklandığı değerlendirilmiştir. Farklı nanoakışkanların yerel Nusselt sayısına (yerel sıcaklık değerine göre hesaplanan Nusselt sayısıdır) etkisi Şekil 12'de sunulmuştur.

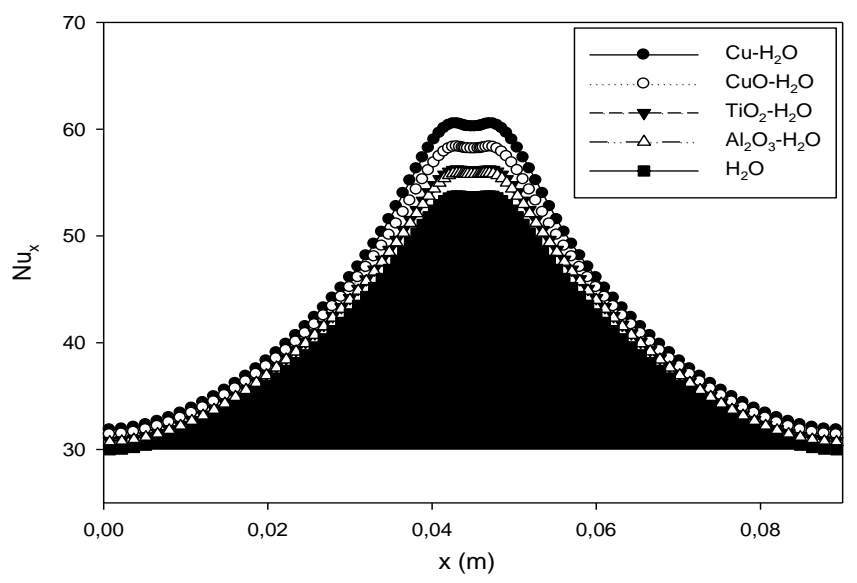

Şekil 12. Farklı nanoakışkanların yerel Nusselt sayısına etkisi

$\mathrm{Cu}-\mathrm{H}_{2} \mathrm{O}$ nanoakışkanın kullanıldığı durumda saf suya göre duvar jeti bölgesinde hız konturlarının daha belirgin şekilde oluştuğu tespit edilmiştir. Bunun sebebinin; nano parçacıkların sebep olduğu yüzeye yakın bölgede oluşan girdaplara bağlı olarak, hidrodinamik sınır tabaka kalınlığının artması olduğu değerlendirilmektedir. $\mathrm{Cu}-\mathrm{H}_{2} \mathrm{O}$ ve saf su için elde edilen hız vektörleri Şekil 1314 'de sunulmuştur. 


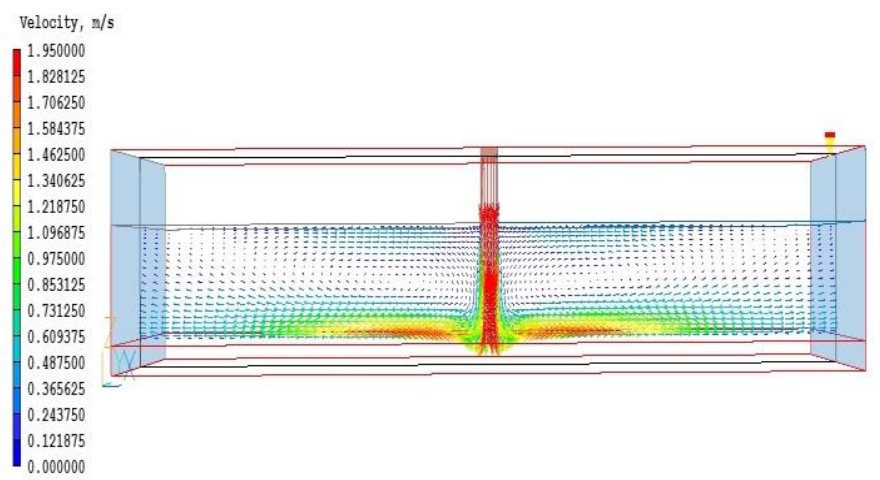

Şekil 13. $\mathrm{Cu}-\mathrm{H}_{2} \mathrm{O}$ nanoakışkanı için hız vektörleri Velocity, $\mathrm{m} / \mathrm{s}$

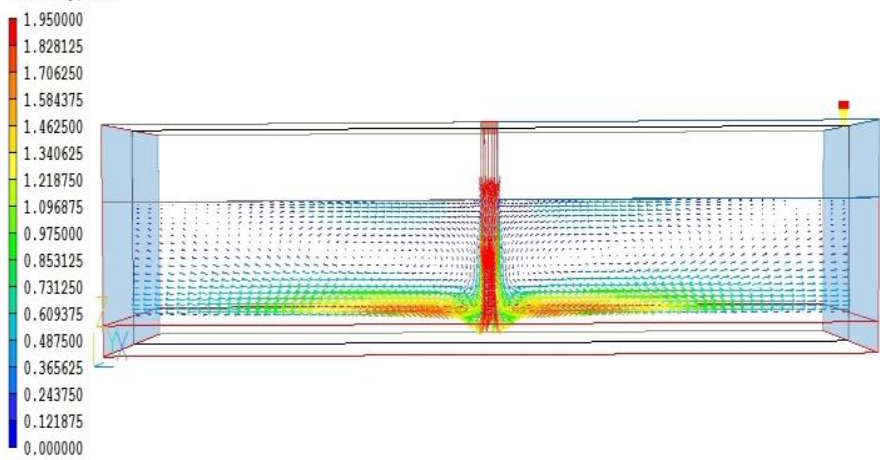

Şekil 14. Saf su için hız vektörleri

$\mathrm{Cu}-\mathrm{H}_{2} \mathrm{O}$ nanoakışkanın kullanıldığı durumda saf suya göre yüzeydeki sıcaklık değerlerinin özellikle çarpma bölgesinde belirgin şekilde azaldığı, buna bağlı olarak oluşan momentum transferi sebebiyle hızlanan akışkanın 1sıl sınır tabaka kalınlığını azalttığı tespit edilmiştir. Nanoakışkan kullanılma durumunda duvar jeti bölgesinde de belirgin şekilde sıcaklık düşüşleri tespit edilmiştir. Özellikle duvara yakın bölgelerde akışkan hızının azalmasına bağlı olarak oluşan yüksek sıcaklık bölgeleri nanoakışkan kullanılma durumunda oldukça azalmıştır. $\mathrm{Bu}$ durumun nano parçacıkların bu bölgelerde oluşturdukları nano boyuttaki girdaplardan kaynaklandığ 1 tespit edilmiştir. $\mathrm{Cu}-\mathrm{H}_{2} \mathrm{O}$ nanoakışkanı ve saf su için elde edilen sıcaklık konturları Şekil 15-16'da sunulmuştur. 


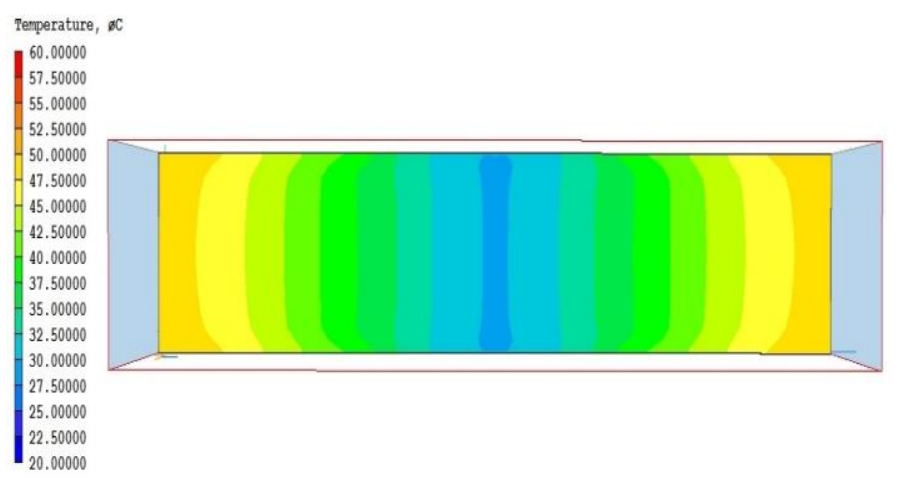

Şekil 15. $\mathrm{Cu}-\mathrm{H}_{2} \mathrm{O}$ nanoakışkanı için sıcaklık konturları

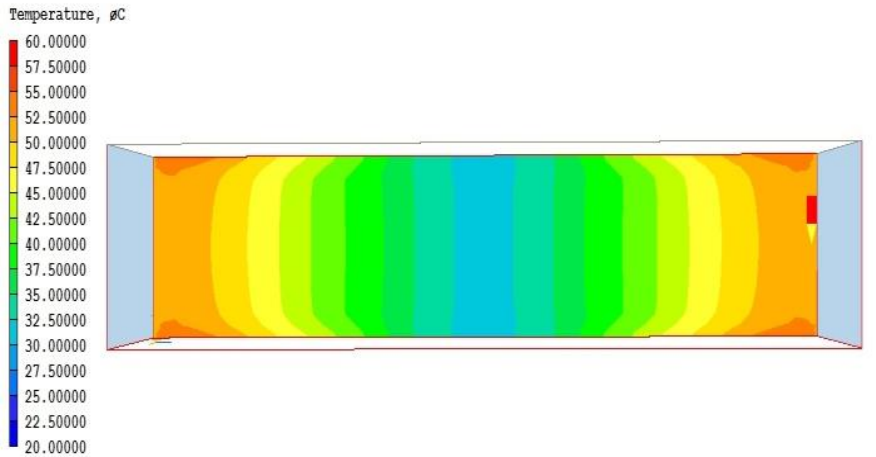

Şekil 16. Saf su için sıcaklık konturları

\section{Sonuç}

$\mathrm{Bu}$ çalışmanın amacı; biyolojik sistemlerde (insan benzeri robotik uygulamalarda, robot kol ya da uzuvların geliştirilmesinde) farklı tipte nanoakışkanlar ve çarpan akışkan jet kullanılarak 1sı transferinin ve akış özelliklerinin incelenmesidir. $\mathrm{Bu}$ maksatla; protez bir elin işaret parmağını modelleyen bakır bir plakadan olan 1sı transferinin iyileştirilmesinde çarpmalı akışkan jetlerin ve farklı tipteki nanoakışkanların etkisi belirlenmeye çalışılmıştır. Sonuç olarak;

Re sayısı arttıkça yerel $\mathrm{Nu}$ sayısının arttığı görülmüştür. Re sayısı 40008000 aralığında artırıldığında $\mathrm{Nu}_{\text {ort }}$ sayısında \%47,2'lik bir artış elde edilebildiği 
görülmüştür. Re sayısı arttıkça çarpan jetlerin yerel soğutma özelliğinin daha belirgin bir şekilde gözlemlenebildiği tespit edilmiştir. Re=2000-4000 aralığında ortaya çıkan $\mathrm{Nu}_{\text {ort }}$ değerindeki artış $\mathrm{Re}=6000-8000$ aralığında ortaya çıkan değerden daha büyüktür. Bunun sebebinin akışkan hızındaki artışa bağlı olarak yüzeyde meydana gelen ayrılmalar olduğu değerlendirilmiştir.

$\mathrm{Cu}-\mathrm{H}_{2} \mathrm{O}$ nanoakışkanı kullanılması durumunda, ortalama Nusselt sayısında sirasiyla $\mathrm{CuO}-\mathrm{H}_{2} \mathrm{O}, \mathrm{TiO}_{2}-\mathrm{H}_{2} \mathrm{O}, \mathrm{Al}_{2} \mathrm{O}_{3}-\mathrm{H}_{2} \mathrm{O}$ ve saf suya göre $\% 2,6, \% 5,5, \% 6,1$, \%9,6 iyileşme olduğu gözlemlenmiştir. $\mathrm{Cu}-\mathrm{H}_{2} \mathrm{O}$ nanoakışkanın kullanıldığı durumda saf suya göre yüzeydeki sıcaklık değerlerinin özellikle çarpma bölgesinde belirgin şekilde azaldığı, buna bağlı olarak oluşan momentum transferi sebebiyle hızlanan akışkanın ısıl sınır tabaka kalınlığını azalttığı tespit edilmiştir. $\mathrm{Cu}-\mathrm{H}_{2} \mathrm{O}$ nanoakışkanın en iyi ısı transferi performansını gösterdiği tespit edilmiştir.

Numerik çalışmada kullanılan, PHOENICS Hesaplamalı Akışkanlar Dinamiği programının Düşük Reynolds Sayılı Türbülans modelinin duvar etkilerini de dikkate aldığından deney sonuçları ile oldukça uyumlu sonuçlar verdiği ( $R e=8000$ için \%15'in altındadır) tespit edilmiştir.

$\mathrm{Bu}$ alanda yapılacak gelecek çalışmalarda askerî sistemlerin ısıl yüklerinin daha verimli bir şekilde soğutulabilmesi maksadıyla; çarpan jetlerde hibrid nanoakışkanların kullanılmasının, yüzeyde oluşan 1S1 transferine ve akış karakteristiğine etkisinin farklı askerî sistem geometrileri için incelenmesinin faydalı olacağı değerlendirilmiştir.

\section{Teşekkür}

Bu çalışma, Adana Bilim ve Teknoloji Üniversitesi'nin 16103021 no'lu Bilimsel Araştırma Projesi ile desteklenmiştir. 


\section{Extended Summary}

\section{Introduction}

New technologies are needed to meet the increasing needs of military systems. Nanotechnology has been assigned as the breakthrough technology of the next century. Nanofluids application is one of the important parts of nanotechnology (Sun et al., 2016).

A nanofluid is defined as a suspension of solid particles which have 1-100 $\mathrm{nm}$ size in a base fluid. Using nanofluid in heat transfer applications expands thermal capacity of the fluid. Interactions and collisions between particles cause to increase in turbulence and turbulence intensity of the transition surface. Turbulence intensity and large surface area enables more heat transfer. Nanoparticles carry $20 \%$ of their electrons at the surface that makes them ready to heat transfer. Another advantage of using nanofluids is the particle agitation cause microconvection in the fluid due to its very small size and therefore increases the heat transfer (Teamah et al., 2015).

One of the optimum heat management techniques that provide high cooling efficiency in new technologies is the jet impinging technique. The jet impinging technique is used to intensify heating, cooling or drying processes on a surface. In this method solid surfaces are cooled by means of fluid jets, resulting in considerable increases in heat transfer as well as energy savings (Isman et al., 2008).

This study is different from the studies at literature by evaluating combined effect of impinging jets and nanofluids for different parameters at biosystems. This study will be the one of the first study of application of nanofluids at biosystems. 


\section{Numerical Model}

Low Re k- $\varepsilon$ turbulence model of PHOENICS CFD code was used for this numerical analysis. It was used $96 \times 15 \times 34$ cells for this numerical model. Cell structure was prepared according to flow conditions. In order to get more precise numerical results, we intensified cell numbers in some region as jet inlet, surface of copper plate. Sweep number was studied between 400 and 2500 and cell number was also studied between 24 and 55. It was obtained that sweep number and cell structure are independent from the results for 600 sweep and 96x15x34 cell.

Heat transfer from surface with convection;

$Q_{\text {convection }}=h \cdot A \cdot \Delta T$

Where $h$ is the heat transfer coefficient, $A$ is the convection surface area, $\Delta T(\Delta T=$ $\left.T_{\text {surface }}-T_{\text {bulk }}\right)$ is the difference between the measured surface temperature and the fluid mean temperature. Nusselt number $(\mathrm{Nu})$ is a dimensionless convection heat transfer coefficient indicating the ratio of heat transfer with convection to heat transfer with conduction (Kilic and Baskaya, 2017).

$N u=\frac{\left(q_{\text {tasnm }} D_{h}\right.}{\left(T_{\text {yüzey }}-T_{\text {yigin }}\right) k_{n f}}$

Where $T_{s}$ is the measured surface temperature, $D_{h}$ is the hydraulic diameter, and $k_{n f}$ is the coefficient of thermal conductivity of the nanofluid. Reynolds number $(R e)$ is used to determine for forced convection whether the flow is laminar or turbulent. Reynolds number based on turbulent flow;

$\operatorname{Re}=\frac{\left(\rho_{n f} \cdot V_{j e t} \cdot D_{h}\right)}{\left(\mu_{n f}\right)}$

Where $\rho_{n f}$ is the nanofluid density, $V_{j e t}$ is the jet velocity, and $\mu_{n f}$ is the nanofluid dynamic viscosity.

The density of nanofluids is (Teamah et al., 2015);

$\rho_{n f}=(1-\varphi) \cdot \rho_{b f}+\varphi \cdot \rho_{p}$ 
Where $\rho_{b f}$ is the base fluid (water) density, $\varphi$ is the volumetric ratio of the nanofluid, and $\rho_{p}$ is the density of the solid particles in the nanofluid. The volumetric ratio of nanoparticles is (Teamah et al., 2015);

$\varphi=\frac{1}{(1 / \omega) \cdot\left(\rho_{p}-\rho_{b f}\right)}$

Where $\omega$ is the density difference between the fluid and the main fluid (water). The nanofluid specific heat is calculated from (Manca et al., 2016);

$C_{p_{n f}}=\frac{\varphi \cdot\left(\rho \cdot C_{p}\right)_{p}+(1-\varphi) \cdot\left(\rho \cdot C_{p}\right)_{f}}{\left(\rho_{n f}\right)}$

Where $C_{p(p)}$ is specific heat of particle $C_{p(f)}$ is specific heat of base fluid. The effective thermal conductivity of nanofluid is (Corcione, 2011);

$$
\frac{k_{e f f}}{k_{f}}=1+4.4 \operatorname{Re}^{0.4} \operatorname{Pr}^{0.66}\left(\frac{T_{n f}}{T_{f r}}\right)^{10}\left(\frac{k_{p}}{k_{f}}\right)^{0.03} \varphi^{0.66}
$$

Where $R e$ is the nanoparticle Reynolds number, $P r$ is the Prandtl number of the base liquid. $k_{p}$ is the nanoparticle thermal conductivity, $\varphi$ is the volume fraction of the suspended nanoparticles, $T_{n f}$ is the nanofluid temperature $(\mathrm{K}), T_{f r}$ is the freezing point of the base liquid.

Nanoparticle Reynolds number is defined as (Corcione, 2011);

$R e p=\frac{2 \rho_{f} k_{b} T}{\pi \mu_{f}^{2} d_{p}}$

$\mathrm{K}_{\mathrm{b}}$ is the Boltzmann's constant. The effective dynamic viscosity of nanofluids defined as (Corcione, 2011);

$\mu_{\mathrm{nf}}=\mu_{\mathrm{bf}}\left(1+2,5 \varphi+4,698 \varphi^{2}\right)$

By using these formulations nanofluids thermalphyical properties (density, thermal conductivity coefficient, specific heat, kinematic viscosity and thermal expansion coefficient) were calculated. Numerical results were obtained by running numerical model with thses properties. 


\section{Results and Discussion}

In this section, numerical results were prepared for two parameters. Effects of different Reynolds number $(\mathrm{Re}=2000,4000,6000$, 8000) and effects of different nanofluids $\left(\mathrm{Cu}-\mathrm{H}_{2} \mathrm{O}, \mathrm{CuO}-\mathrm{H}_{2} \mathrm{O}, \mathrm{TiO}_{2}-\mathrm{H}_{2} \mathrm{O}, \mathrm{Al}_{2} \mathrm{O}_{3}-\mathrm{H}_{2} \mathrm{O}\right)$ on heat transfer are the parameters of this numerical study.

\section{Validation of the Model}

It is observed that numerical geometry was independent from sweep number and cell number when sweep number was 600 and cell number was 96x15x34. This numerical modal was verified with experimental results of Li et al. (2012). It was seen that the low Reynolds number k- $\varepsilon$ turbulence model well represents the temperature distribution and flow properties in this study.

\section{Parametric Analysis}

Combined effects of nanofluids and impinging jets on heat transfer for different Reynolds number $(\operatorname{Re}=2000,4000,6000,8000)$ and diferent types of Nanofluid $\left(\mathrm{Cu}-\mathrm{H}_{2} \mathrm{O}, \mathrm{CuO}-\mathrm{H}_{2} \mathrm{O}, \mathrm{TiO}_{2}-\mathrm{H}_{2} \mathrm{O}, \mathrm{Al}_{2} \mathrm{O}_{3}-\mathrm{H}_{2} \mathrm{O}\right)$ were investigated at this study.

\section{Conclusion}

The aim of this study is investigation of heat transfer and fluid flow with nanofluids and impinging jets at biosystem. For his purpose; combined effects of nanofluids and impinging jets were investigated to enhance heat transfer from a copper plate for modelling the sign finger of prothez hand. As a result;

Increasing Reynolds number causes an increas on local Nusselt number. Increasing Re number from 4000 to 8000 causes an increase of $47.2 \%$ on $\mathrm{Nu}_{\text {avg }}$. 
Using $\mathrm{Cu}-\mathrm{H}_{2} \mathrm{O}$ nanofluid causes an increase of $2.6 \%, 5.5 \%, 6.1 \%, 9.6 \%$ on $\mathrm{Nu}_{\text {avg }}$ according to $\mathrm{CuO}-\mathrm{H}_{2} \mathrm{O}, \mathrm{TiO}_{2}-\mathrm{H}_{2} \mathrm{O}, \mathrm{Al}_{2} \mathrm{O}_{3}-\mathrm{H}_{2} \mathrm{O}$ nanofluids.

It was seen that the low Reynolds number $\mathrm{k}-\varepsilon$ turbulence model of PHOENICS CFD code well represents the temperature distribution and flow properties in this study. Difference between experimental and numerical results is under $15 \%$ for $\mathrm{Re}=8000$.

Using hybrid nanofluids with impinging jets, to solve the problem of high heat loads of military systems to obtain more effective cooling systems, may be one of the future research areas for future.

\section{Kaynakça}

\section{Makaleler}

Corcione, M. (2011). Empirical correlating quations for predicting the effective thermal conductivity and dynamic viscosity of nanofluids, Energy Conversation Management, 52 (1), 789-93.

Dilibal, S., (2016). Nikel-Titanyum ile biyo-ilham robotik parmak ve gripper sistemleri, Kontrol/İTய̈, 10, 16-17.

Isman, M. K., Pulat, E., Etemoglu, A. B., ve Can, M.(2008). Numerical investigation of turbulent impinging jet cooling of a constant heat flux surface, Numerical Heat Transfer, 53(10),1109-1132.

Kang, S.W., Wei, W.C., Tsia, S.H. ve Yang S.H. (2006). Experimental investigation of silver nanofluid on heat pipe thermal performance, Applied Thermal Engineering, 26, 2377-2382.

Kilic, M., Çalışır, T. ve Başkaya, Ş. (2017). Experimental and numerical study of heat transfer from a heated flat plate in a rectangular channel with an impinging Jet, Journal of the Brazilian Society of Mechanical Sciences and Engineering, 39(1), 329-344. 
Kilic, M. ve Baskaya Ş. (2017). Improvement of heat transfer from high heat flux surfaces by using vortex promoters with different geometries and impinging jets, Journal of the Faculty of Engineering and Architecture of Gazi University, 32(3), 693-707.

Li, C., Zhou J. (2007). Experimental and numerical simulation study of heat transfer due to confined impinging circular jet, Chemical Engineering Technology, 30 (10), 1355-1361.

Li, Q., Xuan, Y. ve Yu, F. (2012). Experimental investigation of submerged single jet impingement using $\mathrm{Cu}$-water nanofluid, Applied Thermal Engineering, 36(1), 426-433.

Manca, O., Ricci, D., Nardini, S. ve Lorenzo, G. (2016). Thermal and Fluid Dynamics Behaviours of Confined Laminar Impinging Slot Jets with Nanofluids, International Communications in Heat and Mass Transfer, 70, $15-26$.

McGuinn, A., Persoons, T., O'donovan, T. ve Murray, D. (2007). Surface heat transfer from an impinging synthetic air jet, International Journal of Heat and Mass Transfer, 20, 1333-1338.

Qu, J., Wu, H.Y. ve Cheng, P. (2010). Thermal performance of an oscillating heat pipe with $\mathrm{Al}_{2} \mathrm{O}_{3}$-Water nanofluids, International Communication Heat and Mass Transfer, 37, 111-115.

Shang, F.M., Liu, D.Y., Xian, H.Z., Yang, Y.P. ve Du, X.Z. (2007). Flow and heat transfer characteristics of different forms of nanameter particles in oscillating heat pipe, Journal of Chemical Industry, 58, 2200-2204.

Sun, B., Qu, Y. ve Yang, D. (2016). Heat transfer of single impinging jet with $\mathrm{Cu}$ nanofluids, Applied Thermal Engineering, 102, 701-707.

Teamah, M.A., Dawood, M.M., ve Shehata, A. (2015). Numerical and experimental investigation of flow structure and behavior of Nanofluids 
flow impingement on horizontal flat plate", Experimental Thermal and Fluid Science, 74, 235-246.

Umer, A., Naveed, S. ve Ramzan, N.,(2015). Experimental study of laminar forced convection heat transfer of deionized water based copper (I) oxide nanofluids in tube with constant wall heat flux, Heat Mass Transfer, 52, 2015-2025

Yan, W.M., Liu, H.C., Soong, C.Y. ve Yang, W.J. (2005). Experimental study of impinging heat transfer along rib-roughened walls by using transient liquid crystal technique, Heat and Mass Transfer, 48, 2420-2428.

\section{Yayınlanmış Bildiri Metinleri}

Chien, H.T., Tsia, C.Y., Chen, P.H. ve Chen, P.Y. (2003). Improvement on thermal performance of a disc-shape miniature heat pipe with nanofluid, Proceedings of the fifth International Conference on Electric Packaging Technology, (IEEE), 389-391.

Kilic, M. ve Ozcan, O. (2017) Numerical Investigation of heat transfer and fluid flow of nanofluids with impinging jets, Proceedings of the International Conference On Advances and Innovations in Engineering (ICAIE), 434440. 